WellBeing International

WBI Studies Repository

$1-1984$

\title{
Aquatic Feeding by Moose: Selection of Plant Species and Feeding Areas in Relation to Plant Chemical Composition and Characteristics of Lakes
}

D. Fraser

Ontario Ministry of Natural Resources

E R. Chavez

Macdonald College

J. E. Paleheimo

University of Toronto

Follow this and additional works at: https://www.wellbeingintlstudiesrepository.org/feebeh

Part of the Animal Studies Commons, Behavior and Ethology Commons, and the Comparative Psychology Commons

\section{Recommended Citation}

Fraser, D., Chavez, E. R., \& Palohelmo, J. E. (1984). Aquatic feeding by moose: selection of plant species and feeding areas in relation to plant chemical composition and characteristics of lakes. Canadian Journal of Zoology, 62(1), 80-87.

This material is brought to you for free and open access by WellBeing International. It has been accepted for inclusion by an authorized administrator of the WBI Studies Repository. For more information, please contact wbisr-info@wellbeingintl.org.

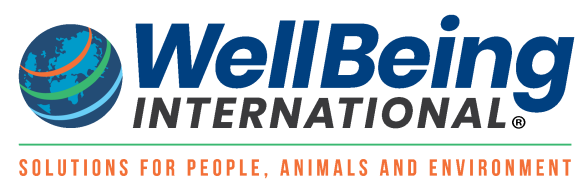




\title{
Aquatic Feeding by Moose: Selection of Plant Species and Feeding Areas in Relation to Plant Chemical Composition and Characteristics of Lakes
}

\author{
D. Fraser ${ }^{1}$, E.R. Chavez ${ }^{2}$, and J.E. Paleheimo ${ }^{3}$ \\ ${ }^{1}$ Ontario Ministry of Natural Resources \\ ${ }^{2}$ Macdonald College \\ ${ }^{3}$ University of Toronto
}

\begin{abstract}
Aquatic feeding by moose was studied with emphasis on $(I)$ the chemical composition of aquatic plants compared with terrestrial browse, (ii) the chemical composition of preferred and unpreferred aquatic plant species and (iii) characteristics of preferred feeding areas. Compared with woody browse, aquatic plants had much higher levels of sodium and iron, and similar levels of other nutrients tested. In a "cafeteria" selection experiment, moose consistently ate seven species of aquatic plants (preferred plants), consistently rejected five species (unpreferred plants), and gave an intermediate response to seven species. Preferred species had significantly higher sodium content. Those in the intermediate class contained more crude protein and phosphorus than unpreferred species. Of 24 lakes and ponds, 6 were heavily used by moose. 16 were used relatively little, and 2 were difficult to classify. The six heavily used sites had shallower water, a higher mineral content in the lake sediment, and a greater abundance of preferred plant species. Plants growing in heavily used sites had higher levels of sodium, phosphorus, and manganese than the same species growing in lightly used sites. Results suggest that levels of sodium in aquatic plants have a major influence on the animals' selection of aquatic plant species and feeding areas, while phosphorus and protein levels may also influence selection.
\end{abstract}

Our name "moose" for Alces alces is an Algonkian word meaning "twig eater." During most of the year this is a fitting description, but in the warm months many moose supplement their woody diet with aquatic vegetation. Paradoxically, aquatic feeding is concentrated in the early summer (Fraser et al. 1982) when twigs and leaves are particularly nutritious (Stewart et al. 1977). Apart from their high mineral content, aquatics have little apparent nutritional advantage over terrestrial plants (Fraser et al. 1980). Furthermore, aquatic feeding imposes certain requirements on the animals: a move to different habitat (Joyal and Scherrer 1978), more costly locomotion (Belovsky and Jordan 1978), and sometimes very inefficient gathering of plant material (D. Fraser, unpublished observations).

The most plausible explanation for this curious behaviour is that moose seek aquatic vegetation because of its high sodium content (Jordan et al. 1973; Botkin et al. 1973). The moose's winter diet of twigs is poor 
in sodium, and an estimated annual sodium budget calculated for moose on Isle Royale suggests that plants rich in the element are necessary to make up an accumulated deficiency (Jordan et al. 1973; Belovsky and Jordan 1980). Alternatively, a change of diet associated with the spring "green up" may cause a temporary need for sodium (Weeks and Kirkpatrick 1976). Whatever the cause, many herbivores show a distinct appetite for supplementary sodium in the spring and summer (Blair-West et al. 1968; Weeks and Kirkpatrick 1978), and the same is true of moose (Fraser and Reardon 1980).

However, there is little direct evidence to indicate that moose do seek aquatic plants as a result of a sodium appetite, and other interpretations are quite possible. Since much aquatic feeding coincides with the period of antler growth and lactation, a demand for calcium, phosphorus, and other minerals might be involved. On the other hand, moose may not use aquatic plants for any special nutrients, but simply as an alternative to woody browse in areas where aquatic vegetation is available.

Our aim in this study was to provide basic information on aquatic feeding behaviour to help assess the different possible interpretations of its significance. Initial work on seasonal variation in aquatic feeding has been reported (Fraser et al. 1982). This paper describes studies on the animals' selection of different aquatic plant species and of different aquatic feeding areas.

\section{Study area}

The study was done in Sibley Provincial Park, Ontario $\left(48^{\circ} 20^{\prime} \mathrm{N} .88^{\circ} 45^{\prime} \mathrm{W}\right)$, a $243-\mathrm{km}^{2}$ peninsula on the north shore of Lake Superior. The forest is principally boreal as described by Rowe (1972). At the time of the study, the moose population in the Park was estimated at 100-200 animals by aerial survey (Ontario Ministry of Natural Resources. unpublished data). The Park includes 37 named lakes and numerous small unnamed lakes and ponds. Most of the water bodies are $<50$ ha, and many are $<2 \mathrm{~m}$ deep. Rock outcropping in the peninsula consists mainly of Precambrian sediments and some intrusive igneous rocks. These impart a higher mineral content to lake waters than is provided by the regionally common granitic rocks of the Precambrian Shield. Soils are mainly silty to sandy till on the west side of the peninsula, and a mixture of till and lacustrine sand on the east.

\section{Methods}

\section{Plant-selection experiment}

To indicate which common plant species arc eaten by moose, "cafeteria" arrays of aquatic plants (separated according to species) were set out beside a Well-used aquatic feeding lake. The plants were harvested by hand between 6 June and 23 July 1979, from 14 lakes in the study area. Samples were kept in pails of lake water. Within $24 \mathrm{~h}$ of collection, they were cleaned of extraneous plant and animal matter, and the remaining material was rinsed in lake water several times. Since the amount of root, flower, and fruit on plants varied between samples, these were removed except in the case of Eleocharis acicularis. a delicate plant whose roots could not be separated efficiently. Samples of Nuphar variegatum consisted of leaf blades of mature plants plus $20-50 \mathrm{~cm}$ of petiole. We harvested Typha latifolia in imitation of moose feeding, by gripping the middle of the plant and pulling upward, yielding leaves attached at the base but without roots.

Plants were presented in plastic pails $10-12 \mathrm{~cm}$ deep, with an opening of $1000 \mathrm{~cm}^{2}$. These were placed in a row about $10 \mathrm{~cm}$ apart on the shore of lake 15D, at a point where moose commonly entered the water. Before and after each trial, plant material in the pails was drained in the air for $5 \mathrm{~s}$ and weighed. Each pail was normally furnished with $400-900 \mathrm{~g}$ of wet plant material of a single species. The pails were checked daily, and the trial was considered complete when the plants in at least one pail were gone $(<25 \mathrm{~g}$ remaining). In case any pail had been overlooked by the moose, pails not consumed were presented a 
second time, interspersed among pails of fresh plants in the next trial. Initially, species were not set out in a fixed order, but as preferences became obvious, preferred and unpreferred species were interspersed as much as possible.

For most trials, all material was taken from a single lake. Hence, the array offered was determined by the species available at that site. This caused imbalance in the arrays, but it was the only feasible approach, and it provided moose with roughly the same selection as would be encountered on visiting the given lake. In total, 19 plant species were used. Each was presented between 3 and 11 times for a total of 109 presentations in 17 trials. Two other trials, which no moose appeared to visit within 5 days, were omitted from the calculations.

\section{Characteristics of the lakes}

Twenty-four lakes and ponds were chosen to give a variety of surface areas, locations, types of shoreline, and types of bedrock. Easily accessible lakes were given preference, but all lakes in the park that were known to be well used by moose were included.

Characteristics of the lakes were studied during several visits to each lake between May 1976 and July 1980. Surface areas were determined from aerial photographs, and approximate depth contours were measured in the field. From these, mean depth and water volume were estimated. Aerial photographs and ground checks were used to sign percentages of shoreline types around each lake, the types being (i) bare bedrock and talus, (ii) peat bog, mainly dominated by Sphagnum, and (iii) soil or stone and soil, mainly dominated by forest but with marshy edges in places. Outflow rate from each lake was estimated in the field in August 1979.

In each lake, scoop of sediment were examined from a canoe at numerous locations where water depth was $<2 \mathrm{~m}$, the zone in which virtually all aquatic feeding was seen. The lake was then divided into two to six sediment zones with a new zone beginning where the nature of the sediment changed noticeably. The zones were marked on a map of the lake, and a composite sample of sediment from each zone was collected and air dried. These were later tested for organic content by loss on ignition and the results were averaged, with weighting based on the relative areas of the different zones.

Water samples were collected to give information on standard limnological measures (specific conductance, total alkalinity, $\mathrm{pH}$, and colour), major plant nutrients (total Kjeldahl nitrogen, total phosphorus, and potassium), sulphate in view of its apparent influence on aquatic vegetation (Moyle 1945), and sodium because of its likely influence on sodium levels in the vegetation. The analytic techniques are described in Anonymous (1975). One midlake surface-water sample was collected from each lake in May-June 1976 and another in July 1977. Specific conductance, total alkalinity, pH, colour, and sulphate showed close agreement between the 2 years, with little seasonal variation as shown by a series of supplementary samples. Therefore, the mean of the 1976 and 1977 values was used for these variables. Nitrogen, phosphorus, potassium, and sodium varied considerably over the season, presumably because of plant metabolism. Therefore, additional samples were collected in May of 1978 and 1979, soon after ice disappeared from the lakes, before significant plant growth became apparent.

Abundance of each aquatic plant species was estimated in August and early September of 1977 for all lakes. A canoe or boat was paddled near the shoreline and in several lines crosscrossing the lake. Areas of $<2 \mathrm{~m}$ depth were divided into sections, with a new section beginning where the nature or abundance of vegetation changed substantially. Sections were marked on an outline map, and the abundance of each species was estimated as the approximate percentage of lake bottom covered by the plants as if seen from above. Estimates for sections were then combined for each lake. The extreme shallowness of 
Joeboy Lake allowed a more precise survey based on 349 plots along four transect lines as described by Fraser and Hristienko (1983).

Moose use of aquatic sites

Preliminary study indicated that the relative amount of aquatic feeding in lakes could be assessed at the end of the feeding season from trail development and other signs near the shore. Accordingly, an observer walked the perimeter of each lake in August and early September 1977. The shoreline was divided into sections marked on an outline map, with a new section beginning where the degree of moose activity appeared to change. Development of moose trails was rated from 0 (no evidence of trails) to 5 (a wide, heavily worn trail, deeply rutted in wet places). Ratings for the sections were then averaged, with weighting based on the section's length, to give a rating for the entire lake. All work was done by a single field worker.

To check the indirect rating of aquatic feeding, direct observations were made on 12 of the most accessible lakes. Observations consisted of 3-h shifts at 0600-0900 and 1800-2100 between mid-June and mid-July, times shown to include the greatest amount of aquatic feeding in a previous study (Cobus 1972).

Table 1. Consumption by moose of the 19 plant species offered in the plant-selection experiment

\begin{tabular}{|lccc|}
\hline Species & No. of presentations & No. completely consumed & Mean \% consumed ( \pm SD) \\
\hline Myriophyllum verticillatum & 7 & 7 & $100 \pm 0$ \\
Utricularia vulgaris & 7 & 7 & $100 \pm 0$ \\
Potamogeton gramineus & 6 & 6 & $100 \pm 0$ \\
P. epihydrus & 6 & 6 & $100 \pm 0$ \\
P. filiformis & 5 & 5 & $100 \pm 0$ \\
P. foliosus & 4 & 4 & $100 \pm 0$ \\
Scirpus subterminalis & 4 & 4 & $100 \pm 0$ \\
Potamogeton alpinus & 5 & 4 & $80 \pm 45$ \\
Sparganium angustifolium & 5 & 4 & $80 \pm 45$ \\
Nuphar variegatum & 8 & 2 & $72 \pm 37$ \\
Potamogeton natans & 7 & 4 & $69 \pm 48$ \\
P. zosteriformis & 4 & 1 & $48 \pm 54$ \\
P. praelongus & 11 & 3 & $33 \pm 44$ \\
P. amplifolius & 10 & 2 & $29 \pm 41$ \\
Eleocharis acicularis & 4 & 0 & $15 \pm 16$ \\
Equisetum fluviatile & 3 & 0 & $5 \pm 9$ \\
Potamogeton robbinsii & 4 & 0 & $4 \pm 3$ \\
Typha latifolia & 5 & 0 & $0 \pm 0$ \\
Characeae (algae) & 4 & 0 & $0 \pm 0$
\end{tabular}

In each shift, an observer watched with binoculars from a canoe, boat, or fixed shoreline location, and made notes on all animals seen as described by Fraser et al. (1982). As a simple measure of moose activity, the number of moose present at the beginning of each 15-min interval of the $3 \mathrm{~h}$ was noted, and the total of these values constituted the "moose-activity core" for each 3-h shift.

A minimum of six shifts was completed for each lake in 1976-1977. Additional shifts (up to 23 in total in 1976-1978) were completed for some lakes, usually as part of other studies. Shifts on each lake were distributed over the month of observations as much as possible, with an equal number of morning and evening shifts on each lake in each year. 


\section{Sampling plants for chemical analysis}

To test several points arising from the results, three sets of plant samples were collected for chemical analysis. ( $I$ ) For each of the 19 plant species in the plant-selection experiment, a double quantity was collected on three occasions, from three different lakes if possible. After being cleaned as described above, the material was divided with about half for the selection experiment and half for chemical analysis. (ii) Because moose appeared to feed more heavily in lakes with a mineral-soil bottom, samples were collected to determine whether vegetation in heavily used mineral-soil areas differed in chemical composition from plants in lightly used locations. Four plant species were selected for study because they could be found in both types of lake. Each species was collected from two lightly used lakes and, depending on availability, from either one or two heavily used lakes. Two samples of each species were collected from each lake for a total of 13 pain; of samples. All sampling was done between 30 June and 2 August 1979. (iii) To compare the chemical composition of aquatic plants and terrestrial browse, four species of woody terrestrial plants used by moose in the summer were collected from each of three sites in the study area. Samples comprised the current-year's growth of twigs and leaves, and were collected between 14 and 26 July 1980.

Material designated for chemical analysis was air dried in the field in net bags. Samples were then ground in a small Culatti mill to pass a 1-mm screen. Small quantities (4-6 g) were weighed in a dried crucible and placed $\mathrm{m}$ a vacuum oven at $95^{\circ} \mathrm{C}$ for $12 \mathrm{~h}$ for determination of dry matter. Nitrogen was determined by the Kjeldahl method (Anonymous 1980). Crude protein was calculated as $N \times 6.25$. Ether extract was measured by Soxhlet extraction with diethyl ether for $18 \mathrm{~h}$. Cellulose was determined as described by Donefer et al. (1960). Ash values were obtained by heating samples in a muffle furnace at $600^{\circ} \mathrm{C}$ overnight. Gross energy was determined in an adiabatic oxygen bomb calorimeter. Samples for mineral analysis were prepared by wet digestion with nitric and perchloric acid (Anonymous 1980). The digest was made up to an exact volume with deionized water. Aliquots were then used to determine the individual mineral elements $\mathrm{Na}$. K, $\mathrm{Ca}, \mathrm{Mg}$. Fe, $\mathrm{Mn}, \mathrm{Zn}$, and $\mathrm{Cu}$ using atomic absorption spectrophotometry (Perkin-Elmer model 360). Phosphorus was determined by the spectrophotometric method (Anonymous 1980) using molybdovanadate reagent. All chemical components were expressed per unit of ovendried matter.

\section{Results and discussion}

\section{Selection of plants by moose in relation to chemical composition}

Moose were seen eating from the pails on only one occasion but tracks suggested that they accounted for all consumption of plants. Of the 17 successful cafeteria trials, moose visited the array of pails and consumed some plants within 1 day in 10 cases, 2 or 3 days in 6 cases, and 5 days in the remaining case. Consumption or rejection of a pail of plants wits usually clear-cut. Of the 109 pails presented, the plants were completely consumed ( $<25 \mathrm{~g}$ remaining) in 59 cases, largely untouched $(<25 \mathrm{~g}$ removed) in 32 cases, and partly removed in the remaining 18 cases.

The animals' selection of plants was usually consistent among trials (Table 1). Seven species were completely consumed every time they were offered (average consumption of 100\%); seven species were eaten completely in some trials but not others (average consumption of 29-80\%); and five species were eaten little or none every time (average consumption of 0-15\%). For the purpose of statistical comparison, the plants were divided into three classes (preferred, intermediate, and unpreferred) based on these differences. 
Chemical composition of the 19 species, divided according to the three classes, is shown in Table 2. Results were analyzed by nested two-way analysis of variance (for class and species within class) after logarithmic transformation to reduce heterogeneity of variance.

Table 2. Chemical composition of the 19 species of aquatic plants used in the plant-selection experiment, divided according to preference classes

\begin{tabular}{|c|c|c|c|c|c|c|c|c|c|c|c|c|c|c|}
\hline Species & $\begin{array}{l}\mathrm{Na} \\
(\%)\end{array}$ & $\begin{array}{l}K \\
(\%)\end{array}$ & $\begin{array}{l}\mathrm{Ca} \\
(\%)\end{array}$ & $\begin{array}{l}\mathrm{Mg} \\
(\%)\end{array}$ & $\begin{array}{l}P \\
(\%)\end{array}$ & $\begin{array}{l}\mathrm{Fe} \\
(\%)\end{array}$ & $\begin{array}{c}\text { Mn } \\
(p p m)\end{array}$ & $\begin{array}{c}\mathrm{Zn} \\
(p p m)\end{array}$ & $\begin{array}{c}\mathrm{Cu} \\
(p p m)\end{array}$ & $\begin{array}{c}\text { Crude } \\
\text { protein } \\
\text { (\%) }\end{array}$ & $\begin{array}{l}\text { Ether } \\
\text { extract } \\
\text { (\%) }\end{array}$ & $\begin{array}{c}\text { Cellulose } \\
(\%)\end{array}$ & $\begin{array}{l}\text { Ash } \\
(\%)\end{array}$ & $\begin{array}{l}\text { Gross } \\
\text { energy } \\
\text { (kJ/kg) }\end{array}$ \\
\hline \multicolumn{15}{|l|}{ Preferred } \\
\hline $\begin{array}{l}\text { Myriophyllum } \\
\text { verticillatum }\end{array}$ & 1.76 & 1.29 & 1.76 & 0.63 & 0.18 & 0.24 & 1036 & 27 & 8 & 17.6 & 1.1 & 30.9 & 12.8 & 16675 \\
\hline $\begin{array}{l}\text { Utricularia } \\
\text { vulgaris }\end{array}$ & 2.09 & 1.98 & 1.27 & 0.80 & 0.15 & 0.39 & 504 & 89 & 14 & 1.36 & 3.0 & 29.7 & 15.1 & 15814 \\
\hline $\begin{array}{l}\text { Potamogeton } \\
\text { gramineus }\end{array}$ & 0.66 & 2.17 & 1.84 & 0.33 & 0.21 & 0.07 & 427 & 66 & 12 & 15.5 & 0.6 & 30.4 & 9.9 & 18268 \\
\hline P. epihydrus & 0.72 & 3.82 & 1.38 & 0.37 & 0.21 & 0.08 & 89 & 102 & 14 & 16.0 & 1.0 & 29.2 & 11.9 & 18542 \\
\hline P. filiformis & 1.07 & 2.40 & 1.49 & 0.39 & 0.25 & 0.19 & 304 & 35 & 8 & 16.2 & 3.8 & 30.1 & 11.7 & 19057 \\
\hline P. foliosus & 0.83 & 1.92 & 1.43 & 0.34 & 0.37 & 0.36 & 306 & 38 & 12 & 20.3 & 1.3 & 27.1 & 11.0 & 18992 \\
\hline $\begin{array}{l}\text { Scirpus } \\
\text { subterminalis }\end{array}$ & 0.63 & 2.24 & 0.30 & 0.42 & 0.19 & 0.28 & 362 & 55 & 14 & 17.0 & 2.0 & 32.1 & 10.2 & 18520 \\
\hline Mean & 1.11 & 2.26 & 1.35 & 0.47 & 0.22 & 0.23 & 432 & 59 & 12 & 16.6 & 1.8 & 29.9 & 11.8 & 17981 \\
\hline \multicolumn{15}{|l|}{ Intermediate } \\
\hline $\begin{array}{l}\text { Potamogeton } \\
\text { alpinus }\end{array}$ & 0.64 & 3.29 & 1.65 & 0.39 & 0.22 & 0.07 & 147 & 109 & 18 & 18.1 & 0.6 & 28.1 & 12.0 & 16042 \\
\hline $\begin{array}{l}\text { Sparganium } \\
\text { angustifolium }\end{array}$ & 0.98 & 3.77 & 1.44 & 0.51 & 0.31 & 0.19 & 694 & 106 & 8 & 19.8 & 1.9 & 21.9 & 14.1 & 18148 \\
\hline $\begin{array}{l}\text { Nuphar } \\
\text { variegatum }\end{array}$ & 0.54 & 1.28 & 1.52 & 0.15 & 0.27 & 0.02 & 57 & 17 & 4 & 18.7 & 2.3 & 21.2 & 6.6 & 19400 \\
\hline $\begin{array}{l}\text { Potamogeton } \\
\text { natans }\end{array}$ & 0.52 & 2.75 & 1.09 & 0.53 & 0.28 & 0.39 & 161 & 74 & 7 & 18.6 & 2.8 & 35.9 & 9.6 & 18803 \\
\hline P. zosteriformis & 0.41 & 1.76 & 1.36 & 0.63 & 0.29 & 0.05 & 187 & 31 & 9 & 18.8 & 1.2 & 37.3 & 8.1 & 18573 \\
\hline P. praelongus & 0.42 & 2.52 & 1.98 & 0.30 & 0.26 & 0.01 & 164 & 47 & 7 & 17.8 & 1.3 & 25.3 & 9.6 & 19183 \\
\hline P. amplifolius & 0.45 & 2.87 & 1.71 & 0.29 & 0.20 & 0.10 & 255 & 55 & 6 & 15.4 & 0.3 & 31.1 & 10.9 & 18487 \\
\hline Mean & 0.57 & 2.61 & 1.54 & 0.40 & 0.26 & 0.12 & 238 & 63 & 8 & 18.2 & 1.5 & 28.7 & 10.1 & 18377 \\
\hline \multicolumn{15}{|l|}{ Unpreferred } \\
\hline $\begin{array}{l}\text { Eleocharis } \\
\text { acicularis }\end{array}$ & 0.33 & 1.43 & 0.69 & 0.28 & 0.22 & 1.16 & 202 & 90 & 25 & 13.5 & 1.3 & 28.1 & 10.3 & 18320 \\
\hline $\begin{array}{l}\text { Equisetum } \\
\text { fluviatile }\end{array}$ & 0.39 & 2.66 & 1.62 & 0.41 & 0.30 & 0.02 & 188 & 105 & 5 & 13.6 & 1.6 & 32.4 & 14.4 & 16313 \\
\hline $\begin{array}{l}\text { Potamogeton } \\
\text { robbinsii }\end{array}$ & 0.52 & 1.45 & 1.94 & 0.30 & 0.18 & 0.15 & 597 & 39 & 6 & 15.5 & 1.1 & 28.7 & 8.2 & 18888 \\
\hline Typha latifolia & 0.40 & 2.00 & 1.11 & 0.36 & 0.16 & 0.01 & 233 & 14 & 3 & 13.1 & 1.4 & 32.3 & 6.9 & 18420 \\
\hline $\begin{array}{l}\text { Characeae } \\
\text { (algae) }\end{array}$ & 0.55 & 0.46 & 12.71 & 0.68 & 0.06 & 0.20 & 352 & 147 & 9 & 14.0 & 0.1 & 30.0 & 28.9 & 12397 \\
\hline Mean & 0.44 & 1.60 & 3.62 & 0.41 & 0.16 & 0.31 & 314 & 79 & 10 & 14.0 & 1.1 & 30.3 & 13.7 & 16868 \\
\hline
\end{tabular}

Note: All values are means of three samples, usually from different lakes, and are expressed per unit of dry matter. 
Table 3. Indirect rating of moose activity for 12 lakes, number of hours of direct observation, number of moose seen per 3-h observation shift. and moose-activity score based on the number of moose present at the beginning of each 15-min interval

\begin{tabular}{|lccccc|}
\hline Lake & Indirect & $\begin{array}{c}\text { Observation } \\
\text { rating }\end{array}$ & $\begin{array}{c}\text { Sightings } \\
\text { per shift }\end{array}$ & $\begin{array}{c}\text { Acore A } \\
\text { (per shift) }\end{array}$ & $\begin{array}{c}\text { Score B } \\
\text { (per shift per ha) }\end{array}$ \\
\hline 7B & 4.6 & 45 & 0.74 & 0.81 & 1.63 \\
24A & 4.4 & 48 & 0.94 & 1.50 & 0.94 \\
Joeboy & 4.3 & 63 & 5.61 & 18.63 & 0.29 \\
Gardner & 4.0 & 69 & 2.80 & 9.24 & 0.20 \\
Lizard & 2.5 & 21 & 1.00 & 4.00 & 0.18 \\
Pickerel & 1.5 & 24 & 0.25 & 0.88 & 0.01 \\
Kay & 1.2 & 18 & 0.34 & 1.34 & 0.19 \\
Grassy & 0.8 & 24 & 0.38 & 0.50 & 0.09 \\
Sawbill & 0.8 & 18 & 0.00 & 0.00 & 0.00 \\
1A & 0.6 & 24 & 0.25 & 1.00 & 0.31 \\
Rita & 0.6 & 42 & 0.00 & 0.00 & 0.00 \\
Calcite & 0.5 & 48 & 0.63 & 0.56 & 0.35 \\
\hline
\end{tabular}

Sodium content varied significantly among classes $\left(F_{2,16}=7.10 ; P<0.01\right)$, with the highest average levels in preferred plants. The studentized Newman-Keuls test, applied to the species means, showed that the preferred species had higher levels of sodium than either the intermediate or unpreferred species $(P<0.05)$, while the latter two groups did not differ significantly.

Levels of phosphorus and crude protein in the different species were closely correlated $(r=0.79)$, and both showed significant variation among classes $\left(F_{2,16}=11.16, P<0.01\right.$ for crude protein; $F_{2,16}=3.93, P$ $<0.05$ for phosphorus). Plants in the intermediate class had higher levels of both phosphorus and crude protein than unpreferred species, and plants in the preferred class had higher levels of crude protein than unpreferred species $(P<0.05$ by the studentized Newman-Keuls test), but the intermediate group did not exceed the preferred species on these measures $(P>0.05)$.

No other chemical constituent showed significant variation among classes. Most constituents had highly significant variation among species within classes; exceptions were phosphorus, zinc, and crude protein.

Moos activity in 24 lakes

Initially we had hoped to rate or rank the moose's preference for the 24 lakes by expressing animal activity per unit of lake area or per unit of potential forage. This proved impossible for several reasons, especially the wide range in lake size. Obviously, large lakes with abundant vegetation could support more feeding than small ones. Hence, any simple measure of moose activity is confounded with lake size. Calculating activity per unit of area also has drawbacks, as large lakes could not compete with small, heavily used ponds unless they attracted a vast influx of moose from surrounding areas.

Fortunately, the indirect ratings of moose activity divided most lakes into two clear categories. Six lakes, called "heavily used lakes," had high ratings of 3.1-4.6, and obviously attracted much moose activity. These generally had abundant plant fragments and heavily worn trails with many summer dung piles. Seventeen lakes, called "lightly used lakes," had low ratings of 0.3-1.6 and appeared to attract little moose activity. Only Lizard Lake, with a rating of 2.5, fell between the two ranges and was not assigned to either category. 
In the 3-h observation shifts, moose were commonly seen in the four heavily used lakes that were studied, but rarely in the lightly used lakes, with the exception of several sightings in Calcite Lake (Table 3). Similarly, records kept during other field work showed frequent sightings in all six of the heavily used lakes, but not in the lightly used lakes, again with the exception of Calcite Lake.

Two quantitative measures of moose activity were calculated, based on the 3-h observation shifts (Table 3 ). Score $A$ is the number of moose present at the beginning of each 15-min interval during the shifts. Score B is the same measure expressed per hectare of lake surface area. Neither score alone gives a valid comparison of the lakes for reasons described above. However, based on multiple linear regression, the two scores together accounted for $81 \%$ of the variation in the indirect ratings.

Hence, although the direct and indirect measures of moose activity cannot be compared in a simple way, the direct observations largely supported the division of lakes into preferred and unpreferred categories. One exception was Calcite Lake which evidently attracted moose despite its low rating based on trail development. However, Calcite was the only lake surrounded by a broad rim of open bog which allowed moose to approach the water from any direction without making the usual trails. Because its indirect rating was not considered comparable to the others, Calcite Lake was omitted from further analysis.

\section{Characteristics of heavily and lightly used lakes}

The 6 heavily used and 16 lightly used lakes differed significantly in only three of the characteristics studied. First, heavily used lakes tended to be more shallow, with a depth of $0.7 \pm 0.4 \mathrm{~m}$ (mean $\pm \mathrm{SD}$ ) as opposed to $1.8 \pm 1.2 \mathrm{~m}$ in the lightly used lakes $(P<0.01$ by the Mann-Whitney U-test, two tailed). Second, the sediments of heavily used lakes were less dominated by organic matter. Estimated organic matter in the sediment, for areas with $<2 \mathrm{~m}$ water depth, averaged $28 \pm 15 \%$ for heavily used lakes and $47 \pm 16 \%$ for lightly used lakes $(P<0.05)$. Third, heavily used lakes had a higher percentage cover by plant species judged as preferred in the plant-selection experiment. Preferred species covered $11 \pm 10 \%$ of areas with $<2 \mathrm{~m}$ water depth in heavily used lakes, compared with $3 \pm 10 \%$ in lightly used lakes $(P<$ 0.01). There were no significant differences between the two classes of lakes in percentage cover by plants in the intermediate or unpreferred classes, nor by plants that were not tested in the plant-selection experiment.

In addition, three of the heavily used lakes had the most substantial flushing rates of water. Based on flow rates of outflow streams in August 1979, a volume equal to that of the lake was estimated to flush through lakes 24A, Joeboy, and Gardner in 3,11, and 60 days, respectively. All other lakes were judged to be passing little or no water $\left(<0.028 \mathrm{~m}^{3} / \mathrm{s}\left(1 \mathrm{ft}^{3} / \mathrm{s}\right)\right)$ in outflow streams at the time of inspection.

\section{Chemical composition of plants from heavily and lightly used lakes}

For the four species of aquatic plants collected from both heavily and lightly used lakes (Potamogeton gramineus, $P$. epihydrus , P. zosteriformis, and P. praelongus), chemical composition was similar to the values given in Table 2. However, there were several differences between samples collected from heavily and lightly used sites. Results were analyzed by two-way analysis of variance for lake type and plant species, after logarithmic transformation to reduce heterogeneity of variance in the case of manganese. As none of the variables showed significant interaction between lake type and species in the analysis of variance $(P>0.05)$, the interaction term was ignored.

Plants from heavily used lakes had significantly higher levels of sodium $\left(F_{1,8}=16.7, P<0.01\right)$, phosphorus $\left(F_{1,8}=27.2, P<0.01\right)$, and manganese $\left(F_{1,8}=8.0, P<0.05\right)$. Crude protein showed a similar trend $\left(F_{1,8}=4.92, P<0.10\right)$. In addition, there were significant differences among species in cellulose, 
gross energy, sodium, potassium, magnesium, and iron $(P<0.05)$. Of the eight lakes where these plants were collected, the three heavily used sites averaged $24 \%$ organic matter in the sediment compared with $43 \%$ in the lightly, used lakes.

\section{Chemical composition of woody terrestrial plants}

Compared with aquatic plants, the four species of woody terrestrial plants had much lower levels of sodium and iron. Other chemical components did not differ substantially between the two groups (Table 4).

\section{General discussion}

\section{Selection of plant species}

In our field notes, the plants identified by observers as being eaten by moose were generally the largest or most conspicuous species such as Potamogeton amplifolius, P. praelongus, Nuphar variegatum, and Typha latifolia. The same trend is apparent in our earlier field study (Fraser et al. 1980), and in the 10 studies summarized by Peek (1974, Table 3). Such observations have often been thought to indicate which plant species are preferred by moose. In the plant-selection experiment, however, the plants that were most consistently eaten were generally the smaller, submersed species which are often consumed while the moose's head is completely under water. We conclude that conventional field observations do not give accurate information on the species of aquatic plants preferred by moose.

Table 4. Chemical composition of four species of woody terrestrial plants eaten by moose in the summer

\begin{tabular}{|c|c|c|c|c|c|c|c|c|c|c|c|c|c|c|}
\hline Species & $\begin{array}{l}\mathrm{Na} \\
(\%)\end{array}$ & $\begin{array}{c}K \\
(\%)\end{array}$ & $\begin{array}{l}\mathrm{Ca} \\
(\%)\end{array}$ & $\begin{array}{l}M g \\
(\%)\end{array}$ & $\begin{array}{l}P \\
(\%)\end{array}$ & $\begin{array}{l}\mathrm{Fe} \\
(\%)\end{array}$ & $\begin{array}{c}\text { Mn } \\
(p p m)\end{array}$ & $\begin{array}{c}\text { Zn } \\
\text { (ppm) }\end{array}$ & $\begin{array}{c}\mathrm{Cu} \\
\text { (ppm) }\end{array}$ & $\begin{array}{c}\text { Crude } \\
\text { protein } \\
(\%)\end{array}$ & $\begin{array}{c}\text { Ether } \\
\text { extract } \\
(\%)\end{array}$ & $\begin{array}{c}\text { Cellulose } \\
(\%)\end{array}$ & $\begin{array}{l}\text { Ash } \\
\text { (\%) }\end{array}$ & $\begin{array}{l}\text { Gross } \\
\text { energy } \\
(\mathbf{k J} / \mathbf{k g})\end{array}$ \\
\hline $\begin{array}{l}\text { Mountain maple } \\
\text { (Acer spicatum) }\end{array}$ & 0.0051 & 1.47 & 1.09 & 0.21 & 0.37 & 0.0062 & 381 & 53 & 10 & 11.5 & 2.0 & 20.4 & 5.4 & 18807 \\
\hline $\begin{array}{l}\text { Pin cherry } \\
\text { (Prunus } \\
\quad \text { pennsylvanica) }\end{array}$ & 0.0051 & 1.60 & 0.99 & 0.28 & 0.34 & 0.0065 & 80 & 37 & 9 & 16.0 & 2.8 & 19.8 & 5.6 & 20058 \\
\hline $\begin{array}{l}\text { Trembling aspen } \\
\text { (Populus } \\
\text { tremuloides) }\end{array}$ & 0.0059 & 1.10 & 0.97 & 0.20 & 0.25 & 0.0041 & 57 & 139 & 12 & 10.4 & 2.7 & 26.9 & 4.2 & 20485 \\
\hline Willow (Salix sp.) & 0.0050 & 1.36 & 1.00 & 0.21 & 0.29 & 0.0060 & 234 & 139 & 10 & 12.7 & 2.0 & 25.9 & 5.4 & 20159 \\
\hline Mean & 0.0053 & 1.38 & 1.01 & 0.23 & 0.31 & 0.0057 & 188 & 92 & 10 & 12.7 & 2.4 & 23.2 & 5.1 & 19877 \\
\hline
\end{tabular}

Note: All values are means of three samples, each from a different location in the study area, and are expressed per unite of dry matter.

Compared with woody browse, the aquatic vegetation contained about 50-400 times more sodium, 2-200 times more iron, and twice as much ash. Aquatics also had slightly more potassium, calcium, magnesium, and manganese, and slightly less phosphorus and ether extract than browse. Most of our values are similar to those reviewed by Hutchinson (1975). High levels of sodium are a common 'feature of aquatic vegetation (Jordan et al. 1973; Hutchinson 1975; Oldemeyer et al. 1977; Boyd 1978). Based on this comparison, if moose seek aquatic plants for specific nutrients that are not sufficiently available in woody browse, then sodium and iron are the most obvious possibilities, although minor trace elements which were not included in this analysis could also be involved (see Franzmann et al. 1975). A seasonal 
demand for calcium and phosphorus, as might be caused by antler growth and lactation, is no, likely to account for aquatic feeding since the aquatic vegetation was not particularly rich in these nutrients.

In the plant-selection experiment, the animals' choice of species was most closely related to sodium content. All of the preferred species contained more than $0.6 \%$ sodium in the dry matter. Of the intermediate group, the two species that were consumed in all but one presentation (Sparganium angustifolium and Potamogeton alpinis) also had sodium levels of more than $0.6 \%$, while the remaining species in the intermediate and unpreferred classes had lower sodium content.

Plants in the intermediate and unpreferred classes did not differ in average sodium content, but the intermediate class had substantially higher levels of phosphorus and crude protein. This suggests that one or both of these constituents may influence palatability if sodium is not an overriding factor.

Other palatability factors may also be involved. Pota mogeton robbinsii and the Characeae were uniformly rejected by moose despite moderate sodium levels of 0.52 and $0.55 \%$. These plants had a stiff, calciumencrusted exterior, and the Characeae give off an unpleasant odour. These features could have contributed to the animals' rejection of the two species.

Interestingly, sodium levels found in this study were consistently higher than those determined for 13 of the same aquatic plant species collected from the study area 3 years earlier (reported by Fraser et al. 1982). However, the ranking of species, from highest to lowest sodium content, was little changed from the previous study. Sodium levels in aquatic plants can show large variation according to site and sampling time, for reasons that are not fully understood (Boyd 1978).

\section{Selection of feeding areas}

The heavily used feeding areas generally had shallow water and a high proportion of preferred plant species. Given the animals' clear preferences for certain plant species in1he selection experiment, it is not surprising that they chose feeding areas where these species were most available. Shallow water provides ideal habitat for growth of aquatic plants, especially the smaller, submersed species that dominated the preferred group. In contrast, many of the plants of intermediate palatability (Potamogeton praelongus, $P$. amplifolius, $P$. natans, and Nuphar variegatum) are generally taller, and thrive in somewhat deeper water. Also, some areas of shallow water became mud flats in dry weather. Presumably this caused oxidation of the exposed lake bottom, and may have produced particularly vigorous growth of plants in subsequent years.

Moose also tended to select lakes whose substrate contained a high proportion of inorganic soil, rather than the soft organic sediments that were common in the less preferred lakes. The inorganic substrates did not appear to be preferred because of any firmer footing that they may have provided. Moose frequently used the central portions of Joeboy Lake where the shallow water $(0.3 \mathrm{~m})$ was underlain with loose sediments more than $2 \mathrm{~m}$ thick. Because they were usually seen with only the head and neck above water, the moose were evidently wading or swimming with most of the body covered in soft lake bottom. Furthermore the sticky clay bottom of preferred lakes 7B and 15D would probably impede movement as much as any of the organic sediments.

The animals' selection of inorganic substrates is more likely related to the vigorous growth and different chemical composition of plants growing in such sites. Many areas of highly organic sediment supported surprisingly little vegetation. By contrast, the shallow lakes with clay or silt substrate appeared to be much more productive. An exclosure study indicated that the heavily used lakes 24A and 7B would be crowded with plants were it not for repeated cropping by moose (Fraser and Hristienko 1983). 
The inorganic lake sediments may have caused greater productivity by making more phosphorus available to the plants. This is supported by the much higher levels of phosphorus in plants collected on inorganic substrates. Availability of phosphorus is a major factor limiting plant life in many lakes (Wetzel 1975 , p. 215); hence, extra phosphorus could have an important influence on plant growth and metabolism. This in turn might account for the higher levels of sodium in plants from inorganic sites. Presumably the high levels of sodium in the plants help to explain why moose are attracted to these sites, but higher levels of phosphorus (and possibly of protein) may also contribute.

In the case of lakes $24 \mathrm{~A}$ and Talus, the largely inorganic substrate began as forest soil which was claimed as lake bottom when the lake was enlarged by flooding. Similarly, the three heavily used feeding areas in the studies of Aho and Jordan (1979) and Fraser et al. (1980) included areas of flooded forest. Flooding of appropriate sites might prove to be a useful way of creating preferred aquatic habitat.

Flow of water may also have influenced the animals' selection of feeding areas. The three lakes with the greatest flow of water (24A, Gardner, and Joeboy) were all well used by moose. Similarly, Fraser et al. (1980) found that moose activity in one lake was concentrated in bays with a substantial flow of water. Like favourable substrates, low-velocity currents can stimulate increased plant growth and metabolic rate (Westlake 1967), but the effect on plant chemical composition is unknown.

\section{Significance of aquatic vegetation for moose}

Jordan and co-workers (Jordan et al. 1973; Botkin et al. 1973), in an astute interpretation of limited data, were the first to suggest that moose are attracted to aquatic vegetation because of its high sodium content. The evidence in this paper lends strong support to this idea. To summarize: $(i)$ of all the nutrients tested, only sodium and iron were much more abundant in aquatic vegetation than in woody browse; (ii) the animals' selection of plant species was more closely correlated with sodium content than with the other nutrients; (iii) the preferred feeding areas generally had a greater abundance of the preferred, sodium-rich species, and often had inorganic substrates that were associated with high levels of sodium, together with certain other nutrients, in the plants.

Jordan et al. (1973) also concluded that moose on Isle Royale require extra sodium because of a deficiency accumulated during the winter. In our area, however, the moose's sodium-related activities do not become common until late May or early June (Fraser et al. 1982), and the period of greatest activity varies from year to year, apparently in relation to the timing of spring phenology (Fraser and Hristienko 1981). These findings are more consisent with the view that the sodium appetite is stimulated by a change of diet caused by the spring green up (see Weeks and Kirkpatrick 1976), rather than an accumulated deficiency persisting from the winter.

Finally, Jordan et al. (1973) propose that sodium is sufficiently scarce on Isle Royale to constitute a limiting factor on the moose population. There, woody plants have very low levels of sodium compared with other areas of moose range (e .g., Oldemeyer et al. 1977), aquatic feeding persists throughout the summer in some years, and the moose cause a marked depletion of aquatic vegetation (Aho and Jordan 1979). Our results are quite different. In the Sibley area, aquatic feeding is much reduced after mid-July. Although vegetation is depleted in certain lakes, preferred species remain abundant in many lakes throughout the summer, and they show little change in major nutrient levels (Fraser et al. 1982). Furthermore, levels of sodium in plants appear to be higher in the Sibley area (e.g., about $50 \mathrm{ppm}$ in summer browse vs. $5-30 \mathrm{ppm}$ on Isle Royale), although discrepancies in analytical techniques might contribute 10 this difference. Taken together, the evidence suggests that moose in the Sibley area are not faced with the severe sodium shortage reported for Isle Royale, and that the animals rectify any imbalance by midsummer without overtaxing the supply of aquatic vegetation. 


\section{Acknowledgements}

We are grateful to Henry Hristienko for assistance throughout the study, Dr. J. K. Morton for checking plant identifications, A. Perras and staff for water analysis, L. Spence for sediment analysis, and K. Macfarlane, A. Hurly, L. Walters, and W. Walters for assistance in the field. The work owes much to the cooperation of the Ministry of Natural Resources staff at Thunder Bay, Sibley Provincial Park, and Maple, and to the support of J. D. Roseborough and C. D. Maclnnes. B. K. Thompson and G. Butler provided valuable discussion and assistance with the statistical treatment. The manuscript benefited from the advice and assistance of D. Baggley, L. Smith, S. Strathearn, and the journal reviewers.

\section{References}

ANONYMOUS. 1975. Outline of analytical methods. Ontario Ministry of the Environment, Toronto, Ont.

ANONYMOUS. 1980. Official methods of analysis. 13th ed. Association of Official Analytical Chemists, Arlington, VA.

AHO, R. W., and P.A. JORDAN. 1979. Production of aquatic macrophytes and its utilization by moose on Isle Royale National Park. U.S. Department of the Interior. National Park Service Transactions and Proceedings, Ser. No. 5. pp. 341-348.

BELOVSKY, G. E., and P. A. JORDAN. 1978. The time-energy budget of a moose. Theor. Popul. Biol. 14: $76-104$.

BLAIR-WEST, J. R., J. P. COGHLAN, D. A. DENTON, J. F. NELSON, E. ORCHARD, B. A. SCOGGINS, R. D. WRIGHT, K. MYERS, and C. L. JUNQUEIRA. 1968. Physiological, morphological and behavioural adaptation to a sodium deficient environment by wild native Australian and introduced species of animals. Nature (London), 217: 922-928.

BOTKIN, D. B., P. A. JORDAN, A. S. DOMINSKI, H. S. LOWENDORF, and G. E. HUTCHINSON. 1973. Sodium dynamics in a northern ecosystem. Proc. Natl. Acad. Sci. U.S.A. 70: 2745-2748.

BOYD, C. E. 1978. Chemical composition of wetland plants. In Freshwater wetlands. Edited by R. E. Good, D. F. Whigham, and R. L. Simpson. Academic Press, New York. pp. 155-167.

Coeus, M. 1972. Moose as an aesthetic resource and their summer feeding behaviour. Proc. North Am. Moose Conf. Workshop, 8: 244-275.

DONEFER, E., E. W. CRAMPTON, and L. E. LLOYD. 1960. Prediction of the nutritive value index of a forage from in vitro rumen fermentation data. J. Anim. Sci. 19: 545-552.

FRANZMANN, A. W., J. L. OLDEMEYER, and A. FLYNN. 1975. Minerals and moose. Proc . North Am. Moose Conf. Workshop. II: 114-139.

FRASER, D., D. ARTHUR, J. K. MORTON, and B. K. THOMPSON. 1980. Aquatic feeding by moose Alces alces in a Canadian lake. Holarct. Ecol. 3: 218-223. ,

FRASER, D., and H. HRISTIENKO. 1981. Activity of moose and white-tailed deer at mineral springs. Can. J. Zool. 59: 1991-2000.

--- 1983. Effect of moose, Alces alces, on aquatic vegetation in Sibley Provincial Park. Can. Field-Nat. 97: 57-61. 
FRASER, D., and E. REARDON. 1980. Attraction of wild ungulates to mineral-rich springs in central Canada. Holarct. Ecol. 3: 36-40.

FRASER, D., B. K. THOMPSON, and D. ARTHUR. 1982. Aquatic feeding by moose: seasonal variation in relation to plant chemical composition and use of mineral licks. Can. J. Zool. 60: 3121-3126.

HUTCHINSON, G. E. 1975. A treatise on limnology. Vol. 3. John Wiley and Sons, New York.

JORDAN, P. A., D. B. BOTKIN, A. S. DOMINSKI, H. S. LOWENDORF, and G. E. BELOVSKY. 1973. Sodium as a critical nutrient for the moose of Isle Royale. Proc. North Am. Moose Conf. Workshop, 9: 1342.

JOYAL, R., and B. SCHERRER. 1978. Summer movements and feeding by moose in western Quebec. Can. Field-Nat. 92: 252-258.

MOYLE, J. B. 1945. Some chemical factors influencing the distribution of aquatic plants in Minnesota. Am. Midi. Nat. 34: 402-420.

OLDEMEYER, J. L., A. W. FRANZMANN, A. L. BRUNDAGE, P. D. ARNESON, and A. FLYNN. 1977. Browse quality and the Kenai moose population. J. Wildl. Manage. 41: 533-542.

PEEK, J. M. 1974. A review of moose food habits studies in North America. Nat. Can. (Que.), 101: 195215.

ROWE, J. S. 1972. Forest regions of Canada. Can. For. Serv. Publ. No. 1300.

STEWART, R. R., R. R. MACLENNAN, and J. D. KINNEAR. 1977. The relationship of plant phenology to moose. Saskatchewan Department of Tourism and Renewable Resources, Tech. Bull. No. 3.

WEEKS, H. P., and C. M. KIRKPATRICK. 1976. Adaptations of white-tailed deer lo naturally occurring sodium deficiencies. J. Wildl. Manage. 40: 610-625.

--- 1978. Salt preferences and sodium drive phenology in fox squirrels and woodchucks. J. Mammal. 59: 531-542.

WESTLAKE, D. F. 1967. Some effects of low-velocity currents on the metabolism of aquatic macrophytes. J. Exp. Bot. 18: 187-205.

WETZEL, R. G. 1975. Limnology. W. B. Saunders Co., Philadelphia. 